\title{
RUMAH TRADISONAL DI DESA ULAK PANDAN SEBAGAI SUMBER PEMBELAJARAN SEJARAH
}

\author{
Oleh: Leo Kusnadi ${ }^{\star}$, Muhamad Idris**, Aan Suriadi ${ }^{* *}$ \\ * Program Studi Pendidikan Sejarah, FKIP Universitas PGRI Palembang \\ ** Program Studi Pendidikan Sejarah, FKIP Universitas PGRI Palembang \\ ${ }^{* * *}$ Program Studi Pendidikan Sejarah, FKIP Universitas PGRI Palembang
}

\begin{abstract}
ABSTRAK
Rumah tradisonal di desa Ulak Pandan kecamatan Semidang Aji Baturaja memiliki nilai sejarah dan nilai budaya yang tinggi. Rumah Aji sebagai rumah adat suku Aji Sub suku Melayu Ogan menjadi saksi perjalanan sejarah selama ratusan tahun. Permasalahan penelitian ini adalah : (1) Bagaimanakah ragam rumah tradisonal di desa Ulak Pandan, (2) Bagaimanakah nilai sejarah dan nilai budaya rumah tradisonal di desa Ulak Pandan. Metode penelitian yang digunakan adalah Metode Deskriptif Kualitatif. Simpulan penelitian: (1) Rumah tradisonal di desa Ulak Pandan merupakan rumah tradisonal yang dibeli langsung dari daerah lliran dan ada yang dibuat di Uluan. (2) Ragam rumah tradisonal yang ada di desa Ulak Pandan merupakan rumah yang berdiri diatas tiang dan juga batu-batu besar atau dengan kata lain ragam bentuk rumah Uluan semuanya berbentuk rumah panggung, sebagai bentuk kearifan lokal menghindari dari bencana alam.
\end{abstract}

Kata Kunci : Rumah Tradisional, Desa Ulak Pandan, Pembelajaran Sejarah

\section{A. PENDAHULUAN}

Masyarakat tradisional Indonesia, pada umumnya memandang rumah sebagai tempat peristirahatan dan tempat menentramkan hati bagi seluruh penghuninya.Dengan alasan inii sudah barang tentu dibangun atau didirikan tidak secara sembarangan, namun pada saat merencanakan dan mendirikan serta selesai didirikan selalu diikuti oleh ritual-ritual atau upacara-upacara tertentu yang biasanya bercorak magis, dengan maksud untuk keselamatan penghuni dan keluarganya serta tukang-tukang yang membangun rumah (Arios, 2012:48).

Proses pergeseran kebudayaan Indonesia, khususnya di pedesaan, telah menyebabkan pergeseran wujud-wujud kebudayan yang terkandung dalam arsitektur tradisonal. pembangunan yang giat yang dilakukan dewasa ini merupakan proses pembaharuan disegala bidang dan pendorong utama terjadinya pergeseranpergeseran dalam bidang kebudayaan, khususnya dibidang arsitektur tradisonal.
Pergeseran ini cepat atau lambat akan merubah bentuk struktur dan fungsi dari arsitektur tradisonal. kenyataan ini menjurus kearah berubah atau punahnya arsitektur tradisonal itu dalam suatu masyarakat (Hanafi, 1985:1).

Makna simbolisme dan fungsi rumah mencerminkan status penghuninya. Manusia sebagai penghuni rumah, budaya serta lingkungannya merupakan satu kesatuan yang erat, sehingga rumah sebagai lingkungan binaan merupakan refleksi dari kekuatan sosial budaya seperti kepercayaan, hubungan keluarga, organisasi sosial serta interaksi sosial antar individu. Hubungan penghuni dengan rumahnya merupakan hubungan saling ketergantungan, yaitu manusia mempengaruhi rumah dan sebaliknya rumah mempengaruhi penghuninya. Menurut Yudohusodo, rumah banyak ditentukan oleh nilai-nilai budaya penghuninya, iklim dan kebutuhan akan pelindung, bahan bangunan, kontruksi, dan teknologi, karakter tapak, ekonomi, 
pertahanan serta agama. Bentuk rumah sangat ditentukan oleh keterjangkauan ekonomi dan pengaruh budaya, yang akan mempengaruhi bentuk fisik lingkungan permukiman. Berdasarkan struktur budaya dapat dibagi menjadi tiga golongan pendapat penghuni, yaitu: rendah, menengah dan tinggi, dimana masingmasing memiliki ciri-ciri, karakter dan fungsi rumah yang berbeda, antara lain, rendah, menengah dan tinggi (Arios, 2012:48).

Ragam hias hadir di tengah-tengah kehidupan masyarakat sebagai media ungkapan perasaan yang diwujudkan dalam bentuk visual, yang proses penciptaannya tidak lepas dari pengaruh-pengaruh lingkungan. la ditujukan sebagai pelengkap rasa estetika. Rupanya di dalam bentuk ragam hias itu terdapat pula makna simbolik tertentu menurut apa yang berlaku syah secara konvensional, di lingkungan masyarakat pendukungnya (Sukanti, 1993:53).

Ragam hias di Sumatera Selatan sudah dikenal sejak zaman prasejarah dan merupakan bagian dari kebudayaan prasejarah. Kemudian pada zaman Neolitikum ragam hias menunjukkan sifat monumental dan simbolis. Masyarakat telah mengenal ukiran yang terdapat pada bangunan dan benda-benda lainnya, misalnya kayu berukir, perahu berukir, hiasan-hiasan pada hubungan rumah dan pada bagian-bagian lainnya yang menunjukkan "lambang" sebagai penolak bala, mendatangkan kebahagiaan dan kemakmuran (Sukanti, 1993: 53).

Indonesia yang memiliki banyak suku bangsa dan beragam kebudayaan yang melimpah. Seperti halnya suku di Sumatera Selatan yang memiliki beragam kebudayaan yang dimiliki seperti rumah-rumah tradisional yang merupakan peninggalan kebudayaan dari nenek moyang mereka. Bangunan rumah tradisional di Sumatera Selatan yang lebih dikenal sebagai rumah Limas dan rumah Ulu. Rumah Limas merupakan ikon budaya tradisional yang identik dengan Palembang sedangkan rumah Ulu adalah sebutan untuk rumah tradisional yang terletak di luar Palembang. Sebagai pusat pemerintahan, Palembang disebut atau dianggap sebagai daerah Ilir (Hilir) sedangkan wilayah kekuasaan yang terletak di luar Palembang disebut sebagai daerah Ulu (Hulu) (Siswanto, 2009:4).

Berdasarkan pendapat di atas, bahwa anggapan yang memberikan pengaruh pada sebutan bentuk rumah tradisional terutama untuk rumah tradisional yang terletak diluar Palembang, yang disebut sebagai rumah Ulu karena terletak di daerah Hulu sedangkan rumah tradisional yang ada di Palembang merupakan rumah limas karena terletak di daerah llir, oleh sebab itu penamaan rumah Ulu dikarenakan daerah berada diluar Palembang sehingga rumah tradisional tersebut untuk masyarakat dinamakan rumah Ulu (Faroby, 2010:4).

Seperti halnya dengan pendapat sebagai berikut: di beberapa kabupaten dan kota di luar Palembang di provinsi Sumatera Selatan, terdapat beragam rumah tradisional yang diklasifikasikan sebagai rumah panggung sekaligus rumah Ulu. Rumah panggung tersebut umumnya memiliki tiang yang diletakkan di atas batu yang berfungsi sebagai pondasi umpak, dengan tiang rumah berada di atas batu atau beberapa butir batu, rumah tradisional menjadi lebih fleksibel terhadap gempa bumi karena dapat bergerak lebih elastis untuk mengurangi pengaruh goncangan akibat gempa bumi tersebut. Rumah tradisional yang memiliki pondasi umpak batu diantaranya adalah rumah Besemah, rumah Semendo, Lamban tuha dan rumah Ulu. Penamaan pada rumah Ulu didasarkan pada letak rumah Ulu. Ulu berasal dari kata "Uluan" sebagai lawan dari perkotaan. Dari pernyataan tersebut dapat diambil kesimpulan bahwa rumah Ulu merupakan rumah yang terdapat pada daerah pinggiran atau pedesaan. Masyarakat membangun rumah Ulu umumnya mengikuti aliran sungai. Ketika itu, masyarakat membangun 
rumah dengan memperhatikan konsep UluUlak (llir). Artinya, apabila tempat tersebut masih luas dan diharapkan akan digunakan juga untuk pembangunan rumah berikutnya maka pembangunan rumah pertama pada lahan tersebut terletak di bagian Ulu. Pada bangunan rumah Uluan banyak dijumpai ragam hias atau motif ukiran yang beraneka ragam, yang ternyata dibuat di samping sebagai ungkapan rasa seni juga sebagai pelambang atau mempunyai makna (Sukanti, 1993: 70).

Berdasarkan uraian diatas penulis berminat untuk meneliti ragam bentuk rumah tradisonal di desa Ulak Pandan Kecamatan Semidang Aji Kabupaten Ogan Komering Ulu. Adapun tujuan penulis ini diantaranya adalah untuk mengetahui bagaimana ragam rumah tradisional di desa Ulak Pandan dan bagaimana nilai-nilai sejarah dan nilai budaya rumah tradisional di desa Ulak Pandan.

\section{B. METODE PENELITIAN}

Metode yang digunakan dalam penelitian ini adalah pendekatan Deskriptif Kualitatif. Berdasarkan rumusan masalah penelitian mendiskripsikan secara merinci dan mendalam mengenai ragam bentuk rumah tradisonal di desa Ulak Pandan sebagai sumber pembelajaran sejarah. Untuk memahami hal tersebut dilakukan penelitian secara mendalam mengenai ragam dan bentuk rumah tradisonal khususnya di desa Ulak Pandan.

\section{Jenis dan Sumber Data}

Jenis data yang digunakan dalam penelitian ini adalah data primer dan data skunder. Data primer yang digunakan dalam penelitian ini diperoleh melalui observasi dan wawancara yang dijabarkan sesuai dengan masalah yang ada pada penelitian ini. Data sekunder didapat melalui bukubuku, majalah, koran, jurnal, dokumen, arsip terbitan pemerintah, foto-foto yang berkaitan dengan masalah dalam penelitian ini. Data tersebut dikumpulkan untuk melengkapi data primer.

\section{Teknik Mengumpulan Data}

Pengumpulan data yang dilakukan penulis mengunjungi perpustakaan sebagai berikut:

a. Perpustakaan Universitas PGRI
Palembang
b. Perpustakaan Daerah Sumatera
Selatan
c. Balai Arkeologi
Selanjutnya teknik Interview yang sering juga disebut dengan wawancara lisan adalah sebuah dialog yang dilakukan oleh wawancara untuk memperoleh informasi dari terwawancara (Arikunto,2010). Mewawancara dengan masyarakat yang tinggal di sekitar Desa Ulak Pandan Kecamatan Semidang Aji Kabupaten Ogan Komering Ulu Provinsi Sumatera Selatan, mengenai ragam bentuk rumah tradisonal dengan cara tanya jawab dengan masyarakat di desa Ulak Pandan.

Teknik observasi dugunakan untuk menggali data dari sumber data yang berupa peristiwa, aktivitas, perilaku, tempat atau lokasi, dan benda, serta rekaman gambar. Teknik dokumentasi, dari asal katanya dokumen, yang artinya barangbarang tertulis. Di dalam melaksanakan metode dokumentasi, peneliti menyelidiki benda-benda tertulis seperti buku-buku, majalah, dokumen, peraturan-peraturan, notulen harian, dan sebagainya (Arikunto,2010).

\section{Teknik Analisis Data}

Teknik analisis yang digunakan dalam penelitian ini adalah analisis model interaktif Miles and Huberman yaitu modal analisis data berlangsung atau menganalisis (plow model analysis). Menurutnya ada empat aktivitas yang dilakukan melalui pendekatan ini yaitu pertama pengumpulan data merupakan proses yang berlangsung sepanjang penelitian, dengan mengunakan seperangkat instrumen yang telah 
disiapkan, guna memperoleh informasi data melalui observasi, wawancara dan dokumentasi. Kedua reduksi data, menunjukan proses menyeleksi, memfokuskan, menyederhanakan, mengabstraksikan, dan mentransformasi data mentah yang muncul dalam penulisan catatan lapangan.

Ketiga display data, adalah usaha merangkai informasi yang terorganisir dalam upaya mengambarkan kesimpulan dan mengambil tindakan. Keempat varifikasi dan menarik kesimpulan, merupakan aktivitas analisis, dimana pada pengumpulan data, seorang analisis mulai memutuskan apakah sesuatu bermakna, atau tidak mempunyai keteraturan, pola, penjelasan, kemungkinan konfigurasi hibungan sebab akibat, dan proposisi.

\section{HASIL DAN PEMBAHASAN Deskripsi Lokasi Penelitan}

Desa Ulak Pandan merupakan salah satu desa yang terletak di kecamatan Semidang Aji Kabupaten Ogan Komering Ulu (OKU) Provinsi Sumatra Selatan. Secara umum kondisi geografis Desa Ulak Pandan termasuk daerah dataran tinggi dan bebatuan itu dilihat dari keadaan tofografi dan ketinggian wilayah Desa Ulak Pandan berkisar antara 90 meter di atas permukaan laut. Adapun secara administratif Desa Ulak Pandan memiliki batas-batas sebagai berikut:

a. Barat berbatasan dengan desa Suka Merindu

b. Selatan berbatasan dengan desa Panggal

c. Timur berbatasan dengan desa Kebon Agung

d. Utara berbatasan dengan desa Nyiur Sayak

Secara administratif Kecamatan Semidang Aji terdiri dari 21 Desa dengan luas wilayah $467.53 \mathrm{Km} 2$, yang terdiri dari berbagai suku, mulai dari suku Padang, Jawa, Sunda dan suku asli yaitu suku Ogan. Adapun jarak kecamatan Semidang Aji dengan ibu kota kabupaten sekitar $35 \mathrm{~km}$, adapun batas wilayah kecamatan Semidang Aji sebelah Barat berbatasan dengan Gunung Kuripan kecamatan Pengandonan, Selatan berbatasan dengan Margha Bakti kecamatan Sinar Peninjauan, sebelah Utara berbatasan dengan desa Rantau Kupai kecamatan Sosoh Buay Rayap (Bappeda OKU, 2012: 23-24).

\section{Ragam Bentuk Rumah Tradisonal di Desa Ulak Pandan}

Di desa Ulak Pandan kecamatan Semidang Aji kabupaten Ogan Komering Ulu memiliki banyak sekali ragam bentuk rumah tradisonal diantaranya: rumah Ulu (rumah Aji), rumah Limas, rumah Gudangan, dan rumah Pedamaran. Menurut hasil wawancara dengan bapak M. Senin yang menyatakan bahwa rumah-rumah yang ada di desa Ulak Pandan adalah rumah tradisonal rumah lliran yang dibeli langsung dari daerah lliran dan dibawa melalui jalur air dan darat dengan cara membeli rumah bongkar pasang dan juga ada yang membuat rumah langsung di daerah Uluan ini tetapi tukang atau yang membuat rumah adalah tukang yang didatangkan dari daerah lliran sehingga motif atau bentuk rumah di desa Ulak Pandan ini semuanya memiliki bentuk yang sama dengan rumah tradisonal lliran (Catatan wawancara 08 Februari 2016 pukul : 19: 30 WIB. M. Senin).

\section{Rumah Ulu (Rumah Aji)}

Rumah Aji ialah salah satu rumah yang terdapat di desa Ulak Pandan, rumah Aji ini merupakan ciri khas rumah Uluan, yang dibagian-bagian ukiran pada rumah ini merupakan percampuran antara dua budaya yaitu lliran dan Uluan yang terkandung dalam sebuah ukiran yang terdapat pada rumah Aji ini. Bentuk rumah Aji yaitu berbentuk empat persegi panjang dengan atap induk rumah berbentuk piramida yang agak curam melebihi 45 derajat. Rumah Aji ini memiliki banyak sekali 
ragam hias pada bagian-bagian rumah seperti: pada tangga, dinding, tiang, kitau, dan jendela.

\section{Nilai Sejarah dan Budaya Rumah Aji}

Budaya adalah daya dari budi, yang berupa cipta, rasa dan karsa, budaya adalah suatu konsep yang membangkitkan minat. Secara formal, budaya didefinisikan sebagai tatanan pengetahuan, pengalaman, kepercayaan, nilai, sikap, makna, waktu, peranan, hubungan ruang, konsep alam semesta, objek-objek materi dan milik yang diperoleh sekelompok besar orang dari generasi ke generasi melalui usaha individu dan kelompok.

Pendirian rumah Aji berbentuk panggung merefleksikan beragam nilai yang hidup dalam masyarakat Uluan, seperti halnya nilai budaya. Nilai budaya yang terkandung dalam pendirian rumah Aji dapat dilihat pada arsitekturnya yang berbentuk rumah panggung yang terbuat dari kayu dengan tiang rumah yang berdiri di atas batu-batu besar, ini tentu memiliki sebuah filosofi tersendiri dalam nilai budaya masyarakat setempat. Bentuk rumah panggung dengan bahan-bahan kayu, nampaknya sebagai penyikapan terhadap kondisi atau tempat berada rumah panggung ini yaitu dipinggir sungai Ogan, dengan kondisi yang memungkinkan rumah akan terendam air maka desain rumah berbentuk panggung merupakan suatu pemecahan yang tepat. Lantai yang tidak berada langsung di atas tanah memungkinkan bangunan tidak akan terendam ketika hujan atau air pasang sedang naik (Catatan observasi No. 02).

Nilai sejarah yang dimiliki rumah Aji di desa Ulak Pandan dapat diketahui melaui hasil survei lapangan. Dilihat dari konstruksi bangunannya pada rumah Aji memilki ukiran dibagian tangga, kitau, pintu depan, dinding rumah yang memiliki makna masing-masing ukiran (Catatan observasi No. 03).

\section{Rumah Limas di Desa Ulak Pandan}

Rumah Limas adalah rumah tradisonal Palembang yang berada di desa Ulak Pandan yang mempunyai ciri khas tersendiri dibandingkan dengan rumah-rumah lainnya yang ada di desa Ulak Pandan, rumah Limas ini berbahan dasar kayu dengan pasak memiliki bentuk arsitertur empat persegi panjang dengan atap yang berbentuk piramida yang agak curam melebihi 45 derajat, rumah limas tidak mempunyai ragam hias atau ukiran pada bagian-bagian rumah seperti rumah Aji. Jenis pintu persegi panjang dengan daun pintu yang sama berbentuk persegi panjang dengan tiang rumah berbentuk bulat.

Hasil observasi yang dilakukan di desa Ulak Pandan Kecamatan Semidang Aji Kabupaten Ogan Komering Ulu di temukan bahwa bentuk arsitektur rumah Limas masih dipertahankan bentuk aslinya oleh pemiliknya, namun terdapat beberapa bagian yang direnovasi (diubah) seperti tiang, awalnya rumah Limas ini semua tiangnya terbuat dari kayu yang berbentuk bulat namun seiring dengan kemajuan zaman atau mungkin tiang yang terbuat dari kayu sudah mulai rusak maka pemilik rumah Limas ini mengganti tiang atau ari rumah ini dengan tiang yang terbuat dari semen.

Di bagian ruang tengah juga sedikit direnovasi tetapi tidak mengubah bentuk aslinya hanya saja pemilik rumah ini mengganti sebaian papan yang ada di ruang tamu yang mungkin sudah lapuk ataupun sudah mulai rusak, sehingga pemilik rumah harus mengganti papan tersebut (Catatan obeservasi No. 04).

\section{Nilai Budaya dan Sejarah Rumah Limas di Desa Ulak Pandan}

Sama halnya nilai budaya yang terkandung dengan rumah Aji yaitu nilai budaya yang terkandung dalam pendirian rumah Limas dapat dilihat pada arsitekturnya yang berbentuk rumah panggung yang terbuat dari kayu dengan tiang rumah yang berdiri di atas batu-batu 
besar, ini tentu memiliki sebuah filosofi tersendiri dalam nilai budaya masyarakat setempat. Bentuk rumah panggung dengan bahan-bahan kayu, nampaknya sebagai penyikapan terhadap kondisi atau tempat berada rumah pangung ini yaitu dipinggir sungai Ogan dengan kondisi yang memungkinkan rumah akan terendam air maka desain rumah berbentuk panggung merupakan suatu pemecahan yang tepat. Lantai yang tidak berada langsung di atas tanah memungkinkan bangunan tidak akan terendam ketika hujan atau air pasang sedang naik (Catatan observasi No. 05). Nilai sejarah yang dimiliki rumah Limas di desa Ulak Pandan dapat diketahui melaui hasil survei lapangan jika dilihat dari konstruksi bangunannya memiliki 2 tiang yang berada di ruang utama, pada rumah Limas memilki jendela yang menggunakan plepek (Catatan observasi No. 06).

\section{Rumah Pedamaran di Desa Ulak Pandan}

Rumah Pedamaran ini merupakan konsep rumah llirian juga dengan bentuk arsitektur yaitu empat persegi panjang. Rumah Pedamaran ini sama halnya dengan rumah-rumah sebelumnya yaitu berbahan dasar kayu namun dibagian bawahnya sudah ditambah atau di renovasi oleh pemilik rumah yaitu ruangan yang terbuat dari batu bata atau dibetton, namun dibagian atas rumah ini masih tetap utuh seperti rumah-rumah lainya yang terbuat dari kayu, namun rumah Pedamaran ini tidak memiliki ragam hias atau ukiran di bagian-bagian dinding, pintu, tiang, maupun pada bagian tertentu lainnya seperti rumah Limas. Rumah Pedamaran ini diperkirakan untuk masyarakat umum dan dari kemampuan yang ekonomi yang sedang (Catatan observasi No. 07).

\section{Nilai Budaya Rumah Pedamaran}

Berdasarkan hasil observasi yang dilakukan pada rumah Pedamaran bahwa nilai budaya yang terdapat pada rumah Pedamaran dapat kita lihat melalui bahan pembuatan rumah yaitu terbuat dari kayu dan berdiri tinggi diatas tiang-tiang yang berada diatas batu-batu besar ini disebabkan karena memungkin agar masyarakat terhindar dari banjir serangan binatang buas dan yang paling utama fungsi dari tiang yang berdiri diatas batu-batu besar yaitu untuk menghindari hancur atau rusaknya rumah bila terjadi gempa (Catatan observasi No. 08).

Nilai budaya yang dimiliki pada rumah Pedamaran yaitu pada bangunan atas rumah rumah ini berbentuk empat persegi panjang yang tidak memiliki ukiran dibagianbagian tertentu rumah ini seperti rumah limas dan rumah gudangan, namun rumah Pedamaran memiliki nilai budaya tersendiri yaitu pada cara pembuatan bagian atas rumah yang tidak memiliki lubang udara (ventilasi) karena disesuaikan dengan keadaan di desa Ulak Pandan yang memiliki cuaca yang cukup dingin pada malam hari (Catatan observasi No. 09).

\section{Rumah Gudangan}

Rumah gudangan yang dimiliki ibu Nasimah merupakan salah satu rumah tradisional yang dimilki provinsi Sumatera Selatan khususnya desa Ulak Pandan, secara keseluruhan bangunan rumah gudangan ini menggukan kayu-kayu pilihan yang tersedia di wilayah kecamatan Semidang Aji. Kayu-kayu yang digunakan pada rumah gudangan ini memiliki kualitas tinggi, hal ini dapat dilihat dari kondisi rumah walaupun usia rumah sudah mencapai ratusan tahun namun bangunan rumah ini masih tetap utuh (Catatatan Obeservasi No.11).

Ukuran rumah gudangan ini cukup besar yakni panjang rumah 19 meter dan lebar rumah 7,50 Meter dan tinggi rumah yang dihitung berdasarkan tiang yakni 2,17 Meter dan rata dari diameter tiang sendiri sekitar $40 \mathrm{~cm}$, tiang yang digunakan pada rumah gudangan ini berjumlah 21 tiang. Kemudian rumah gudangan ini mempunyai teras depan, ruang tamu, ruang keluarga, 2 
kamar tidur, serta dapur, dan bagian depan dan belakang masing-masing memiliki 2 anak tangga.

\section{Fungsi Rumah Di Desa Ulak Pandan}

Fungsi bagian-bagian rumah yang terdapat di desa Ulak Pandan kecamatan Semidang Aji kabupaten Ogan Komering Ulu sebagai berikut:

a. Tiang adalah penyangga bangunan rumah yang terbuat dari kayu pilihan, berbentuk lingkaran bertingkat. Tiangtiang utama berukuran lebih besar, adapun untuk tiang-tiang tambahan berukuran lebih kecil. Ketinggian dari tanah membentuk panggung yang bervariasi disesuaikan dengan kebutuhan. Ketinggian panggung memisahkan lantai rumah dengan tanah atau air di bawahnya, sehingga rumah terhindar dari banjir dan hewan liar.

b. Tangga (Tangge). Tangga pada rumah Uluan sering disebut dengan Tangge. Tangga berfungsi sebagai pijakan untuk menaiki rumah. Jumlah anak tangga biasanya ganjil atau genap.

c. Lintut (Garang). Setelah naik tangga, maka ruangan pertama yang dijumpai adalah garang, yaitu ruangan terbuka yang diberi pagar. Garang biasanya dipergunakan untuk duduk-duduk santai oleh anggota keluarga. Garang juga digunakan untuk menerima tamu yang masih bujang atau tetangga dekat. Tamu yang masih asing juga diterima ditempat ini.

d. Pintu (Lawang). Pintu pada rumah Uluan sering disebut dengan Lawang. Pintu adalah lubang untuk jalan masuk dan keluar rumah berbentuk persegi panjang. Pintu terbuat dari papan kayu tidak menggunakan engsel. Sebelum melewati pintu utama, terdapat pagar yang di pasang didepan pintu yang disebut dengan jarau.

e. Haluan-kakudan. Ruang haluankakudan merupakan ruang keluarga. ruang ini dipergunakan untuk memenuhi beberapa fungsi antara lain untuk menerima tamu, pada ruangan ini tidak disediakan meja kursi. Para tamu duduk diatas lantai berbahan dasar bilah yang sering kali dibentangkan tikar lampit atau kasha, yaitu sejenis tikar yang terbuat dari anyaman rotan. Ruang haluan ini juga digunakan untuk menampung aktifitas adat, kebudayaan dan agama. Ruang ini juga digunakan untuk meletakkan mayat apabila ada salah satu anggota keluarga yang meninggal dunia. Pada umumnya mayat diletakkan pada ruang haluan sebelum dibawa kepemakaman. Pada saat ada acara perkawinan kedua mempelai duduk di ruang ini untuk melangsungkan akad nikah. Pada ruangan ini biasanya terdapat lemari kayu dan ranjang besi. Ranjang besi biasanya digunakan sebagai tempat tidur anak laki-laki.

f. Kamar (Bada Tidok). Kamar merupakan ruangan pribadi yang berfungsi sebagai tempat tidur keluarga. Pada ruangan kamar lantainya tebuat lebih tinggi dari ruangan lainnya. Ruangan kamar ini biasanya terdapat dua atau tiga ruang. Pada masing-masing pintu kamar dibuat lankahan. Seluruh anggota keluarga kecuali anak bujang dapat tidur di dalam kamar.

g. Dapur (Pawon). Dapur pada rumah Uluan disebut juga dengan pawon. Pawon digunakan untuk melakukan kegiatan keseharian seperti memasak, mencuci piring, dan kegiatan kewanitaan lainnya. Oleh karena itu berbagai macam perlengkapan memasak terdapat di ruangan pawon. Peralatan dan perlengkapan itu antara lain: periuk, singkup (untuk tutup membuat kue), kuali, cerek, kukuran (parut kelapa), batu penyaring air minum, rak piring yang terbuat dari kayu, tungku, dan sebagainya.

h. Jendela (Lawang kecek). Jendela adalah lubang untuk masuknya cahaya 
serta tempat sirkulasi udara yang bisa dibuka dan ditutup. Daun jendela pada rumah Uluan terbuat dari papan kayu dipasang secara vertikal, dan terdapat dua bukaan. Pada rumah Uluan biasanya tidak terdapat lubang angin sebagai tempat sirkulasi udara, yang menjadi tempat sikulasi adalah jendela dan pintu utama.

i. Lantai (gladak). Lantai terbuat dari papan, pemasangan papan lantai ini menyamping kekanan dan kekiri ruang rumah.

j. Dinding adalah bagian rumah yang berfungsi sebagai penutup ruang atau penyekat atau pelindung rumah dengan alam sekitar. Dinding rumah Uluan ini dibuat dari papan yang dipasang rapat dalam posisi membujur atau melintang.

k. Flafon. berfungsi menahan bintik-bintik hujan yang masuk dari atap. Panaku ini juga digunakan untuk menyimpan barang-barang yang berguna.

I. Atap (Bubungan). Atap adalah penutup atas pada bagian rumah yang berfungsi melindungi rumah dari sengatan sinar matahari dan hujan. Atap pada rumah Uluan ini menggunakan bahan dari genteng atau seng.

m. Tiber angin (Tibing layar). Tutup pada bidang segitiga atap pada bagian atas samping kanan dan kiri rumah yang berfungsi sebagai penahan hempasan angin dan hujan yang masuk ke dalam rumah melalui sisi kiri atau kanan rumah.

n. Tanduk kambing, yaitu berupa kayu berbentuk silang yang dipasang dibagian atap atap rumah dan berfungsi sebagai penahan atap rumah seperti genteng dan seng agar tidak jatuh tertiup angin.

\section{Pokok Temuan}

Hasil observasi yang dilakukan di desa Ulak Pandan kecamatan Semidang Aji kabupaten OKU, ditemukan bahwa ragam bentuk rumah tradisonal yang ada di desa
Ulak Pandan adalah rumah panggung, rumah tradisonal di desa Ulak Pandan yang peneliti teliti berjumlah empat rumah yang masih mempertahankan bentuk aslinya. Namun, terdapat beberapa bagian yang telah diubah seperti pada rumah Padamaran yang sudah mengubah tiang yang diganti dengan semen. Pada rumah Uluan terdapat pengaruh dalam aspek pelestarian lingkungan. Aspek pelestarian lingkungan dapat diuraikan sebagai berikut:1) Bahan-bahan yang digunakan dalam pembuatan rumah tradisonal di desa Ulak Pandan merupakan bahan dari alam yang ramah lingkungan, contohnya tiang yang digunakan berbahan dasar kayu. Pembuatan rumah Uluan tidak menggunakan bahan-bahan kimia yang akan menyebabkan pencemaran, terutama pencemaran tanah. Dengan demikian, kerusakan lingkungan dapat diminimalisir; 2) Penggunaan kayu yang baik sebagai bahan pembuat rumah tradisonal dapat meminimalisir penebanagan pohon di hutan. Hal ini dikarenakan kayu yang digunakan adalah kayu yang tidak mudah lapuk, sehingga dapat bertahan dari generasi ke generasi berikutnya; 3) Rumah tradisonal yang ada di desa Ulak Pandan berbentuk panggung dapat meminimalisir tinggi banjir walaupun dalam satu wilayah terdiri dari rumah-rumah yang banyak. Hal ini dikarenakan rumah tradisonal yang ada di desa Ulak Pandan berdiri diatas tiang-tiang yang tinggi dan tiang rumah berdiri diatas batu-batu besar yang berfungsi agar dapat mengurangi getaran pada saat terjadi gempa bumi. Dengan tingginya tiang rumah apabila terjadi banjir, maka luapan air dapat mengalir melalui bawah rumah.

\section{Pembahasan}

Daerah Sumatera Selatan mempunyai banyak ragam dan bentuk rumah adat. Masing-masing rumah mempunyai ciri-ciri tersendiri, dengan konsep pembagian ruang yang berbeda-beda. Meskipun beragam bentuknya rumah adat di Sumatera Selatan 
pada umumnya didirikan diatas panggung. Rumah merupakan bangunan tempat tinggal atau tempat bernaung, yang dimaksud rumah tempat tinggal adalah rumah yang dihuni oleh manusia dan didalamnya mereka dapat melakukan aktivitas untuk memenuhi kebutuhan hidupnya dengan sebaik-baiknya. Rumah adalah bangunan yang berlantai, berdinding, dan beratap, berpintu, dan berjendela, tempat diam orang, bermacammacam bentuk dan ukurannya serta pembuatannya (Cimailing, 2014:13).

Rumah Uluan adalah rumah tradisonal masyarakat Uluan Sumatera Selatan. Rumah warga ini memiliki ukuran yang besar, sedang dan kecil, dengan kualitas bahan yang bervariasi. Rumah kelas atas memiliki ukuran besar dengan kayu kelas 1 yang dihiasi dengan ornamen ukiran dengan motif berbunga dan daun yang dilengkapi dengan hiasan geometris. Sehingga menjadi daya dukung ekonomi wilayah Komering pada masa lampau adalah dari sektor hasil kehutanan, pertanian, dan perkebunan. Damar merupakan komoditas utama dalam perdagangan wilayah Uluan dengan lliran. Damar merupakan bahan bakar utama untuk kebutuhan penerangan rumah tangga dan kebutuhan kosmetik. Komoditas lainnya adalah getah gambir, biji pinang, beras dan ternak.

Ragam bentuk rumah tradisonal di desa Ulak Pandan termasuk pada materi Pembelajaran IImu Pengetahuan Sosial Terpadu (Sejarah) di Kelas VIII Sekolah Menengah Pertama ada pada Standar Kompetensi: 7. Mendeskripsikan warisan budaya daerah setempat sedangkan Kompetensi Dasar: 7.3. Menguraikan perilaku masyarakat dalam perubahan sosial-budaya di era global. Materi Pembelajaran: Warisan budaya daerah setempat Karena Ragam bentuk rumah Uluan di desa Ulak Pandan dapat disesuaikan dengan SK dan KD di atas maka sesuai dengan warisan budaya daerah setempat. Ragam bentuk rumah tradisonal di desa Ulak Pandan merupakan salah salah rumah tradisional yang perlu dilestarikan dan harus dimanfaatkan sebagai bahan pembelajaran karena rumahrumah tersebut adalah aset yang harus dijaga keberadaannya. Untuk mewujudkan hal di atas sebagai contoh, ketika pembelajaran sejarah lokal mengenai materi tentang ragam bentuk rumah Uluan. Setiap siswa ditugaskan untuk mencari tahu tentang rumah-rumah Uluan di desa Ulak Pandan. Dengan sendirinya siswa akan berusaha akan mencari informasi dengan tugas yang diberikan.

\section{SIMPULAN}

Ragam bentuk rumah tradisonal di desa Ulak Pandan yaitu rumah Aji, rumah Limas, rumah Pedamaran, rumah Gudangan, yang berdiri diatas tiang/panggung karena untuk menghindari dari bencana alam seperti banjir dan gempa.

Rumah tradisonal di desa Ulak Pandan merupakan rumah tradisonal yang dibeli dari daerah Iliran dan dibawa melalui jalur air dan darat. Rumah bongkar pasang ada juga yang dibuat di desa dengan mendatangkan tukang lliran, sehingga motif atau bentuk rumah di desa Ulak Pandan ini semuanya memiliki bentuk yang sama dengan rumah tradisonal lliran.

Ragam bentuk rumah tradisonal ada pada Standar Kompetensi: 7. Mendeskripsikan warisan budaya daerah setempat sedangkan Kompetensi Dasar: 7.3. Menguraikan perilaku masyarakat dalam perubahan sosial-budaya di era global. Materi Pembelajaran: Warisan budaya daerah setempat Karena Ragam bentuk rumah Uluan di desa Ulak Pandan dapat disesuaikan dengan SK dan KD di atas maka sesuai dengan warisan budaya daerah setempat. 
DAFTAR PUSTAKA

Arikunto Suharsimi. 2010. Prosedur Penelitian Suatu Pendekatan Praktik. Jakarta: PT. Rineka Cipta

Arios, Rois Leonard, dkk. 2012. Bunga Rampai Budaya Sumatera Selatan "Budaya Basemah di Kota Pagar Alam". Padang: BPSNT Padang Press.

Cimailing Novia. 2014. Bentuk dan Makna Simbolik Arsitektur Rumah Ulu di Desa Surabaya Kabupaten OKU Timur Sumatera Selatan. Universitas PGRI Palembang.
Hanafi, dkk. 1985. Arsitektur Tradisonal Daerah Bengkulu. Jakarta: Departemen Pendidikandan Kebudayaan Proyek Inventarisasi dan Dokumentasi Kebudayaan Daerah.

Suryanegara Erwan, dkk. 2009. Ragam Hias di Sumatera Selatan. Palembang: Dinas Pendidikan Provinsi Sumatera Selatan.

Sukanti, dkk. 1993. Rumah Ulu Sumatera Selatan. Palembang: Departemen Pendidikan danKebudayaan Provinsi Sumatera Selatan. 